\title{
KORT KRONIEK VAN MILITÊRE OPERASIES EN OPRTREDES IN SUIDWES-AFRIKA EN ANGOLA (1914 - 1988)
}

\author{
deur kol C.J. Nöthling *
}

South Africa's first military involvement in South West Africa took place during the early part of World War I when, following a request from Britain, an expeditionary force of 67,000 men was mobilised which led to the capture of the territory from Germany.

Some minor actions followed in the intervening years but the first infiltration by SWAPO occured during 1966 but was contained by police action. However by 1973 terrorist activity had increased to the extent that the South African Defence Force was obliged to take over this counterinsurgency role. The extensive border with Southern Angola which included terrein favourable for terrorist activity forced the RSA to take preventative measures. As a result a series of semiconventional operations were launched against SWAPO bases in Southern Angola.

This article describes the various operations that were launched during the ensuing period until 1988 and which led eventually to discussions between South Africa, Cuba and the MPLA to cease hostilities. This settlement plan made provision for the implementation of Resolution 435 and the withdrawal of Cuban forces from Angola.

\section{Inleiding}

Die aanvaarding van Resolusie 435 deur die Verenigde Volke (VVO) se Veiligheidsraad in September 1978 het die weg aangedui vir ' $n$ onafhanklike Suidwes-Afrika/Namibië (SWA). In weerwil van die optimistiese vooruitsig dat SWA spoedig onafhanklik sou wees, is die implementering van Resolusie $\mathbf{4 3 5}$ met meer as ' $n$ dekade vertraag.

In die volgende dekade het die Suid-Afrikaanse magte verskeie militêre voorsprongoperasies teen die basisse van SWAPO-terroriste in Angola van stapel laat loop. In dieselfde tydperk het die Angolese burgeroorlog, wat in 1975 'n aanvang geneem het, verbete voortgewoed. Die militêre scenario in suidwestelike Afrika is verder afgerond deur die opbou van Kubaanse magte en groot hoeveelhede wapentuig in Angola. Die beëindiging van vyandelikhede in die gebied was gewis een van die vernaamste struikelblokke in die weg van 'n vreedsame grondwetlike skikking in SWA. Dit is bereik met die ondertekening van die drieparty- en bilaterale ooreenkoms by die VVO in New York op 22 Desember 1988.

Na die ondertekening van hierdie ooreenkomste, het die Suid-Afrikaanse Minister van Buitelandse Sake, mnr Pik Botha, opgemerk dat die swaar verliese wat die Suid-Afrikaanse magte die vyand (magte van die MPLA-bewind en Ku- baanse troepe) by die Lombarivier in SuidoosAngola toegedien het (Operasie Moduler, 1987), die keerpunt was wat tot die drieparty-ooreenkoms gelei het.

In die konstitusionele ontwikkelingsgeskiedenis van SWA het diplomasie gewis ' $n$ belangrike rol gespeel. Terselfdertyd kan die invloed wat militêre faktore in die politieke ontwikkeling van SWA uitgeoefen het, nouliks oor die hoof gesien word. In hierdie artikel word 'n krygshistorise perspektief gebied van die Suid-Afrika se betrokkenheid in suidwestelike Afrika wat met die Uniemagte se inval in Duits-Suidwes-Afrika in 1914 ' $n$ aanvang geneem het.

\section{Eerste Wêreldoorlog}

Suid-Afrika (SA) het in 1914 na die uitbreek van die Eerste Wêreldoorlog die eerste keer in SWA betrokke geraak toe 'n ekspedisiemag van 67000 man op versoek van Brittanje gemobiliseer is om die gebied van Duitsland te verower. Gedurende die veldtog in Duits-Suidwes-Afrika het die Suid-Afrikaanse magte die Duitse magte binne ses maande met ' $n$ verlies van slegs 266 man tot oorgawe gedwing. Die gebied van $825000 \mathrm{vk} \mathrm{km}$ is tydelik onder Suid-Afrikaanse militêre bestuur geplaas.

Militêre bestuur in SWA is op 17 Desember 1920 beëindig toe die gebied deur die Volkebond 


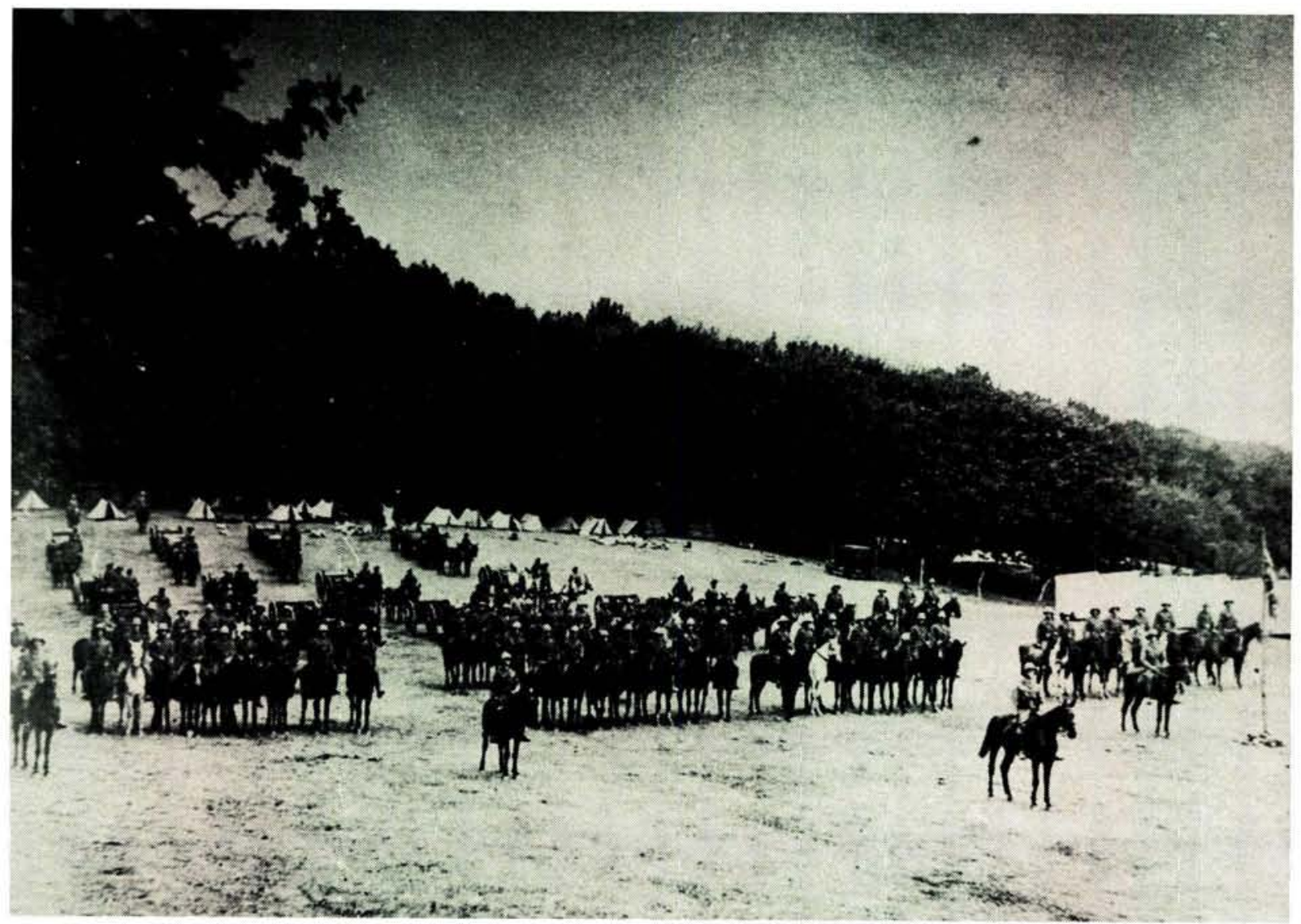

Die kamp van die THA te Groote Schuur (Kaapstad) net voor hul vertrek na Duits-Suidwes-Afrika in Januarie 1915

ingevolgde die mandaatstelsel onder SA se administrasie geplaas is.

\section{Die Bondelswarts-rebellie (1922)}

Die volgende operasionele optrede van die Unieverdedigingsmag in SWA het in 1922 plaasgevind toe die Bondelswarts-stam onder kaptein Jacobus Christian in opstand gekom het omdat die owerheid nie aan hul eise rakende die grense van hul reservaat wou toegee nie. Nadat die stamkaptein geweier het om om aantaal van sy volgelinge wat hul aan wangedrag en diefstal skuldig gemaak het, uit te lewer, is 'n mag van 400 man in SWA op die been gebring. Die hulp van die Suid-Afrikaanse Lugmag is ingeroep om die opstand te beëindig. Die rebelle wat in gevegte by Driehoek en Berg Kanmer swaar verliese gely het, is uiteindelik op 2 Junie 1922 tot oorgae gedwing teen welke tyd die Lugmag 105 operasionele ure sonder verliese gevlieg het. Meer as 100 rebelle is dood terwyl net twee lede van die veiligheidsmagte omgekom het. Die Lugmag is ook in 1932 met welslae aangewend om onluste wat in die noorde van SWA deur stamhoof Ipumbu aangeblaas is, te onderdruk.

\section{Militêre optredes in 1925 en 1933}

In April 1925 het die Rehoboth-basters in opstand gekom waarop die regering besluit het om drie vliegtuie van die Suid-Afrikaanse Lugmag na SWA te stuur. Op 4 April het die vliegtuie van Louisvale opgestyg en oor Keetmanshoop na die Rehoboth-gebied gevlieg. Lugoperasies teen die opstandelinge het die volgende dag begin en is binne enkele ure suksesvol afgehandel. Hierna is lugoperasies ook in ander gebiede onderneem.

In Julie 1932 het die owerheid in SWA probleme met die hoof van die Ukuambi-stam ondervind. Drie vliegtuie van die Suid-Afrikaanse Lugmag en twee pantserkarre is vanaf Pretoria na Owamboland gestuur en die stamhoof is tot oorgawe gedwing.

\section{Tweede Wêreldoorlog (1939 - 1945)}

$\mathrm{Na}$ Adolf Hitler se bewindsoorname in Duitsland het die invloed van die Nazi-party ook in SWA toegeneem. Gedurende die dertigerjare het Hitler openlik aangedring op die teruggawe van die vroeëre Duitse kolonies. Tydens die ampstermyn 
van dr D.G. Conradie het militante Nazi-organisasies heelwat onrus in SWA veroorsaak. Dit het die owerheid genoop om op te tree en teen die einde van 1939 was 150 Nazi-gesinde leiers reeds geïnterneer. In Oktober 1940 het 1200 Duitssprekendes hulle in interneringskampe bevind.

\section{Eerste gewapende botsings met SWAPO $(1966$ - 1968)}

In 1965 het die South West African People's Organisation (SWAPO), wat in 1958 as die Ovamboland People's Congres (OPC) gestig is, besluit om terreuraanvalle in SWA te loods. SWAPO-terroriste van die organisasie se militante vleuel, PLAN (People's Liberation Army of Nambia), het Owamboland binnegesypel en 'n basis by Ongulumbastie_gestig.

Op 26 Augustus 1966 het 'n polisiemag die kamp in ' $n$ verrassingsaanval vernietig. Twee terroriste is doodgeskiet en nege gevange geneem. In dieselfde jaar het drie ander terroristegroepe die grens na SWA oorgesteek en in Owamboland bedrywig geraak. In een geval in September 1966 het die grensdorpie Oshikango onder skoot gekom. In Maart 1967 is 'n polisiepatrollie in Wes-Caprivi in ' $n$ hinderlaag gelok, maar feitlik al die terroriste is later doodgeskiet of aangekeer. In Mei 1967 het SWAPO nog 'n terugslag gekry toe hul opperbevelhebber, Tobias Hanyeko, tydens 'n skermutseling langs die Zambesirivier doodgeskiet is.

In die volgende tien maande is verdere welslae teen die terroriste behaal en teen April 1968 het die veiligheidsituasie dermate verbeter dat die SA Polisie sy teeninsurgensie-personeel aan Owambo kon onttrek. In dieselde jaar is 20 SWAPO-leiers, insluitende Herman Toivo ja Toivo, tot lewenslange tronkstraf gevonnis vir oortreding van die Wet op Terrorisme.

In Oktober 1968 het twee groot terroristegroepe egter opnuut in Owambo begin optree. Altesame 56 terroriste is binne een week na hul aankoms in Owambo aangekeer en PLAN het hierna weer in kleiner groepies opgetree.

\section{Noodtoestand en toetrede van die SA Leër (1972 - 1974)}

'n Uitgebreide staking in SWA het in Januarie 1972 gelei tot die afkondiging van 'n noodtoestand in SWA se noordelike gebiede. Terselfdertyd is eenhede van die Suid-Afrikaanse Weer- mag (SAW) daarheen gestuur om te help met die handhawing van wet en orde.

In Januarie 1973 is 'n nuwe offensief van terreuraanvalle geloods. In een voorval is 'n polisiekamp aan gekonsentreerde outomatiese geweervuur onderwerp. Die toename in terroristeaktiwiteite het daartoe gelei dat die SA Leër in dieselfde jaar die teeninsurgensie-taak oorgeneem het.

\section{Operasie Savannah (1975 - 1976)}

In 1974 was die einde van die Portugese bewind in Angola reeds in sig. Die onstabiele veiligheidsituasie in Angola en die bedreiging wat dit vir SWA ingehou het, het gelei tot die ontplooiing van 'n Suid-Afrikaanse beskermingsmag van slegs sowat 2000 man in SWA se noordelike grensgebied. Hierdie mag, wat die FNLA en UNITA ondersteun het, het te staan gekom teen 'n groot oormag van Kubaanse en MPLA-magte, maar het desondanks skitterende oorwinnings behaal. In 'n "Blitzkrieg" het Taakmag Zulu die suidwestelike hoek van Angola herower nadat Pereira de Eca, Rocades en verskeie ander dorpe ingeneem is.

In Sentraal-Angola het Veggroep Foxbat in Oktober 1975 die vyand by Liumbala verslaan. Hierna het Taakmag Zulu verdere oorwinnings by Cacula en Catengue behaal. Die oorwinnings by Catengue in November 1975 het die vyand gedwing om die Benguela-front te ontruim.

Taakmag Zulu en Veggroep Foxbat het die vyand in die Santa Comba-gebied aan die Celafront gestuit en 'n oorwinning in die slag van Ebo behaal. In die ooste van Angola het Veggroep XRay (later herdoop tot Veggroep Orange) ook oorwinnings by Luso behaal.

Taakmag Zulu en Veggroep Foxbat se oorwinning by die slag van Brug 14 aan die sentrale front is wel bekend. Die slag het plaasgevind nadat die Suid-Afrikaanse magte na Quibala opgeruk het. Hulle moes egter die Nhiarivier by Brug 14 (wat deur die vyandelike magte vernietig is) oorsteek en hier het die genietroep te midde van 'n hewige geveg die brug herstel. Hierna kon die brug oorgesteek en die aanmars op Cassamba en Almeida voortgesit word. $\mathrm{Na}$ die inname van hierdie dorpe het die Suid-Afrikaanse magte opdrag ontvang om nie met die aanslag op Quibala voort te gaan nie.

In Januarie 1976 het die Suid-Afrikaanse magte opdrag gekry om te ontbreek en op 25 Januarie 


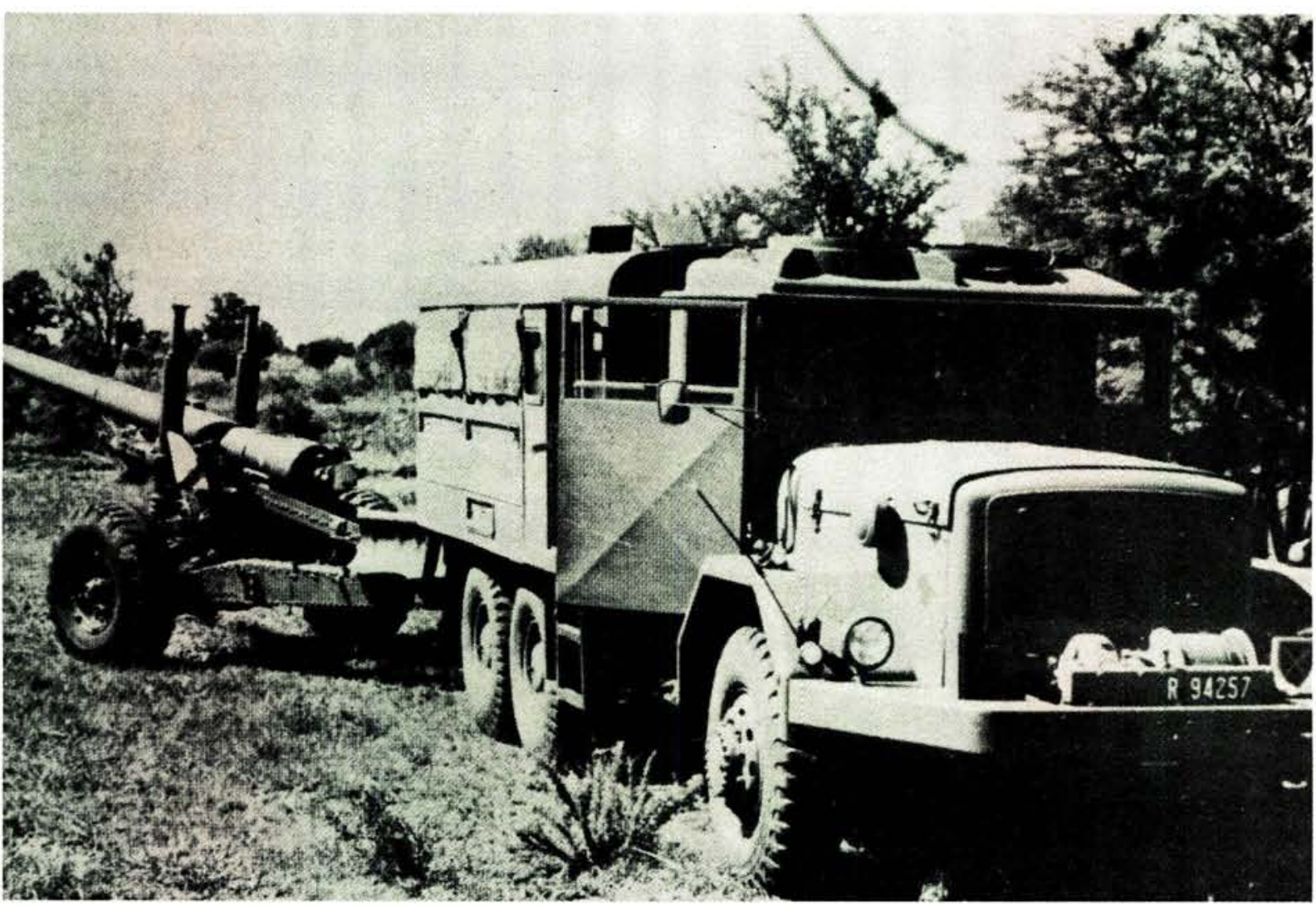

'n 140-mm kanon word deur 'n Magirus Deutz gedurende die veldtog in Angola (Operasie Savannah) gesleep

1976 was die onttrekking afgehandel. Burgermageenhede wat as vier veggroepe in Suid-Angola ontplooi is om die Calueque/Ruacanawaterskema en vlugtelingskampe te beskerm, het Angola op 27 Maart 1976 verlaat.

\section{Operasie Reindeer (1978)}

$\mathrm{Na}$ die onttrekking van die Suid-Afrikaanse magte aan Angola in 1976 was PLAN (wat gedurende Operasie Savannah aan bande gelê is) in staat om ' $n$ uitgebreide netwerk van opleidingsen basiskampe in die suide van Angola te vestig van waar dit SWA kon binnesypel.

Toenemende terrorisme deur SWAPO weens hul maklike toegang tot Owambo oor Angola se oop suidelike grens, het Suid-Afrika genoop om tot ' $n$ beleid van voorsprongoperasies oor te gaan.

Die besluit het gelei tot ' $n$ reeks semi-konvensionele operasies teen primêre SWAPO-basisgebiede en -fasiliteite in Suid-Angola. Die eerste operasie van die aard - Reindeer - is op 4 Mei 1978 geloods en het bestaan uit 'n lug- en valskermaanval op SWAPO se belangrikste opleidings- en logistieke ondersteuningsbasis by Cassinga (bekend as "Moskou") en ' $n$ grond- aanval deur 'n gemeganiseerde mag op verskeie voorste deurgangsbasisse in die grensgebied insluitende ' $n$ uitgestrekte kompleks (bekend as "Vietnam") naby Chetequera, 28 km noord van die grens.

Byna ' $n$ duisend terroriste het gesterf en tweehonderd is gevang terwyl net ses lede van die veiligheidsmagte gesneuwel het. Groot hoeveelhede toerusting en voorrade is vernietig en waardevolle dokumente gebuit. Die verlies van opgeleide personeel en die effek van die inligting wat deur die veiligheidsmagte verkry is, was 'n groot terugslag vir SWAPO waarvan hy nooit volkome herstel het nie.

\section{Operasies in Oos-Caprivi (1978)}

In Junie 1978 is vasgestel dat SWAPO besig was met voorbereidsels vir ' $n$ aanval op die militêre basisse by Katimo Mulilo, Wenela en Mapacha. Ten einde die aanval die hoof te bied, is twee vegspanne, nl Alpha en Bravo, op die been gebring.

Die aanval het op 23 Augustus begin met 'n wegstaanbestoking op Katima Mulilo met 


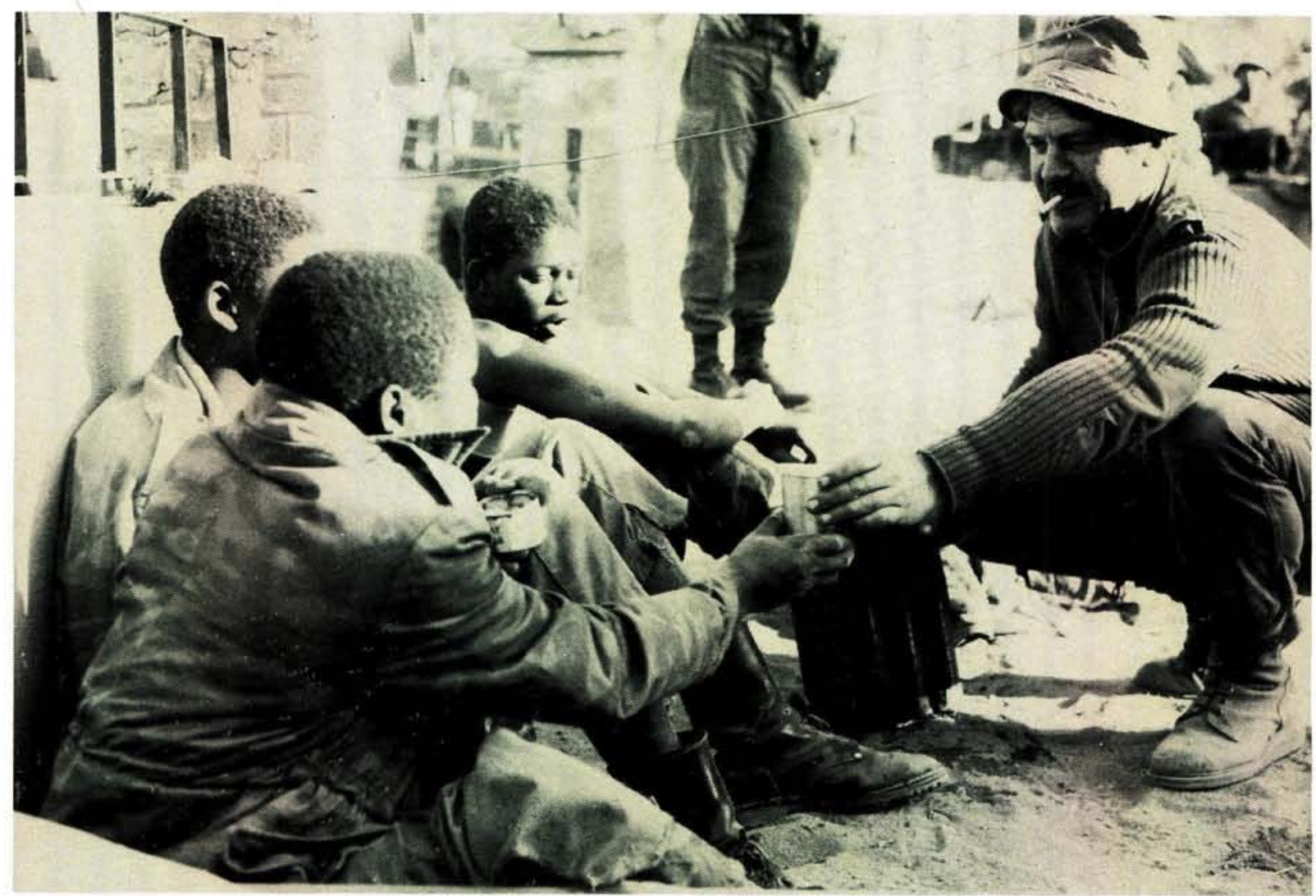

'n Offisier van die Suid-Afrikaanse magte gee kos en water aan drie SWAPO-terroriste wat tydens 'n voorsprongoperasie in Angola gevang is

$122 \mathrm{~mm}$ vuurpyle. Een hiervan het deur die dak van 'n kaserne gedring en 10 soldate gedood.

$\mathrm{Na}$ die beeïndiging van ' $\mathrm{n}$ artillerie- en mortiergeveg het die twee vegspanne die grens oorgesteek. Vegspan Bravo se teiken was 'n SWAPObasis sowat $30 \mathrm{~km}$ van die grens in Zambië, maar dit is verlate gevind en die vegspan het onverrigtersake na Mapacha teruggekeer. Vegspan Alpha het daarin geslaag om die agterhoede van ' $n$ aantal vlugtende terroriste in te haal, maar is in ' $n$ hinderlaag ingelok. In die daaropvolgende geveg is vyf terroriste dood terwyl sowat sestig op die vlug geslaan het. In 'n latere skermutseling by ' $n$ terroristebasis het sewe terroriste omgekom.

Op 25 Augustus het vegspanne Alpha, Bravo en Charlie Papa (wat uit 'n ondersteunings-valskermkompanie, ' $n$ kompanie van 31 Bataljon en 'n troep $140 \mathrm{~mm}$ kanonne saamgestel is) die grens na Zambië weer oorgesteek en na terroristebasisse by Imusho, Cinzenbela en elders opgeruk, maar almal was reeds ontruim. Die enigste noemenswaardige voorval het by $\mathrm{Cin}$ zenbela plaasgevind toe die plaaslike garnisoen met ' $n$ lugafweerkanon op ' $n$ helikopter van die Suid-Afrikaanse Lugmag losgebrand het. Dit is deur Vegspan Bravo se artillerie uitgeskiet. Die vegspanne het op 27 Augustus oor die grens teruggetrek.

\section{Operasies Safraan en Rekstok (1979)}

Die volgende twee groot operasies - Safraan en Rekstok - is vroeg in Maart 1979 van stapel laat loop. Beide operasies is genoodsaak deur die teenwoordigheid van groot getalle SWAPO-terroriste in Zambië wat besig was met voorbereidsels om teikens in SWA aan te val.

Gedurende Operasie Safraan, wat in vier fases plaasgevind het, is verskeie SWAPO-basisse in die omgewing van Sinjembele en die Njinje-bos (Zambië) aangeval en vernietig. SWAPO het wyslik besluit om nie terug te veg nie en sy basisse in Zambië te ontruim nog voordat hulle aangeval kon word. Tydens Operasie Rekstok is terroristebasisse by Muongo, Oncua, Henhombe Heque en elders in Angola aangeval.

\section{Operasies Sceptic en Klipkop (1980)}

Operasie Sceptic het in Junie 1980 begin as ' $n$ blitsaanval op 'n SWAPO-basis in Suid-Angola, maar het ontwikkel tot 'n uigebreide operasie 
soos meer en meer SWAPO-opslagplekke in die gebied ontdek is. Operasie Sceptic het die eerste ernstige botsings met die Angolese magte, FAPLA, meegebring. Daar was ook vir die eerste keer kontak met gemeganiseerde elemente van SWAPO. SWAPO het sy voorste basisfasiliteite verloor terwyl 380 terroriste omgekom het. Etlike honderd ton toerusting en voorrade, asook talle voertuie is deur die veiligheidsmagte gebuit. Sewentien lede van die Suid-Afrikaanse aanvalsmag het gesneuwel.

Operasie Klipkop (Junie 1980) was heelwat kleiner in omvang en het die ontwrigting van SWAPO se voorste logistieke ondersteuningstelsel ten doel gehad.

\section{Operasies Carnation en Protea (1981)}

Die botsings met FAPLA in Operasie Sceptic was die voorspel tot verdere botsings gedurende Operasies Carnation en Protea in Julie en Augutus 1981. SWAPO het as gevolg van sy terugslae in 1980 sy basisse verder noord tot naby en selfs tussen dié van FAPLA geplaas om sodoende aanvalle deur die SA veiligheidsmagte te ontmoedig. SWAPO se logistieke stelsel het ook feitlik onlosmaaklik met dié van FAPLA verstrengel geraak.

Teen die middel van 1981 het die militêre situasie in SWA se noordelike grensgebied 'n ernstige wending geneem. Die stapeling van groot hoeveelhede wapentuig en die opbou van FAPLA- en SWAPO-magte in Suid-Angola het 'n wesentlike konvensionele bedreiging vir SWA ingehou. In Julie 1981 het verskeie skermutselings tussen die veiligheidsmagte en PLAN voorgekom. Die bevelvoerende generaal van die SWA Gebiedsmag het op 6 Julie aangekondig dat 52 terroriste in die bestek van slegs vier dae in gevegte met die veiligheidsmagte doodgeskiet is. Hierdie skerp toename in skermutselings met SWAPO-terroriste het die veiligheidsmagte genoop om Operasie Carnation van stapel te stuur.

Hoewel 225 terroriste gedurende hierdie operasie doodgeskiet is, was dit net gedeeltelik geslaagd. Die veiligheidsmagte het nie verder as 25 kilometer noord van die grens opgetree nie terwyl die groter terroristebasisse verder noord geleë was.

In hierdie tyd het FAPLA self ook 'n meer uittartende houding teenoor die veiligheidsmagte ingeneem. Sy lugverdedigingstelsel het ' $n$ besliste

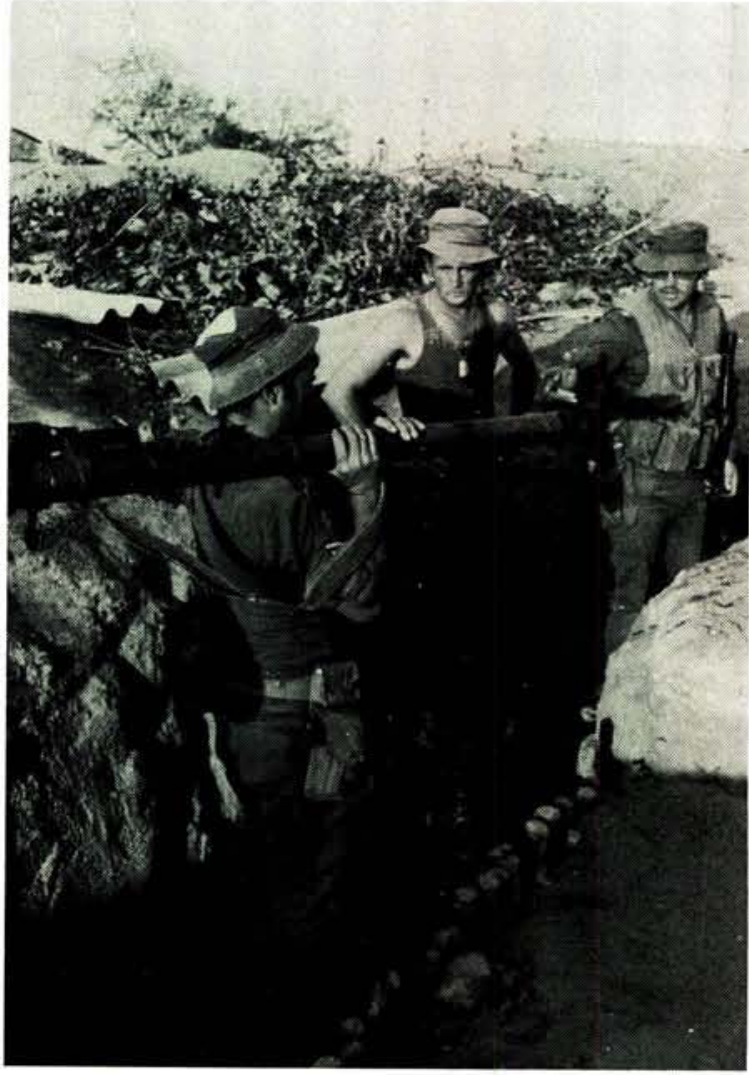

'n Suid-Afrikaanse soldaat met 'n buitgemaakte geleide SA-7 grondlugmissiel-lanseerder in 'n loopgraafstelsel by Xangongo. Die foto is tydens Operasie Protea geneem

bedreiging ingehou vir Suid-Afrikaanse ondersteunings-operasies gedurende Operasie Protea.

Gedurende Operasie Protea is verskeie SWAPO-basisse en bevelsposte in die omgewing van Xangongo en Ongiva deur drie taakmagte aangeval en uitgewis. Dit het op $23 \mathrm{Au}$ gustus 1981 begin met 'n lugaanval op 'n FAPLA-radarstasie en sleutelpunte van die Angolese lugverdedigingstelsel.

Op 24 Augustus het die grondmagte se aanmars langs drie afsonderlike roetes na Xangongo 'n aanvang geneem. 'n Gemeganiseerde mag het basisse by die dorp aangeval waar die hoofkwartier van SWAPO se noordwestelike front gevestig was. Terselfdertyd het ander elemente SWAPO-basisse suid en suidoos van die dorp uitgewis. Xangongo is geïsoleer en afgesny van enige moontlike inmenging deur FAPLA-magte vanaf Humbe en Peu Peu in die noordweste en noordoose onderskeidelik. Die gemengde mag van SWAPO/FAPLA-verdedigers is na 'n kort aanslag op die tenks en infanterie wat in en om die dorp ingegrawe was, verdryf. 
Nadat FAPLA en SWAPO uit Xangongo verdryf is, het die hoofmag oos en suid beweeg en die FAPLA-mag by Mongua uit sy pad gestoot. Die aanval op Ongiva het op 26 Augustus 1981 plaasgevind en die dorp is op 28 Augustus ingeneem nadat ' $n$ ander gesamentlike SWAPO/FAPLA-mag wat in en om die dorp ingegrawe was, verslaan is. Verskeie Sowjet-offisiere is in hierdie geveg dood terwyl 'n Russiese adjudantoffisier gevange geneem is. SINAPO-fasiliteite in en om Ongiva is hierna vernietig en die operasie het op 10 September 1981 ten einde geloop.

Operasie Protea was die grootste gemeganiseerde operasie deur die SA Leër sedert die einde van clie Tweede Wêreldoorlog. In hierdie operasie het die veiligheidsmagte tien man verloor, teenoor die meer as 1000 ongevalle van SWAPO en FAPLA. Onder die sowat vierduisend ton toerusting wat gebuit is, was verskeie tenks en pantserkarre, ' $n$ groot hoeveelheid lugafweerkanonne en sowat 200 logistieke voertuie.

\section{Operasie Daisy (1981)}

Operasie Protea het voortgespruit uit die inligting wat tydens vroeëre operasies verkry is en het op sy beurt inligting verskaf wat gelei het tot die volgende groot operasie - Daisy - wat op 1 November 1981 geloods is. ' $n$ Gemeganiseerde mag het tot die diepse punt sedert die Angolese burgeroorlog ingedryf. Teikens is by Bambi en Cheraquera aangeval. Hoewel daar geen botsings met FAPLA se grondmagte was nie, het 'n paar MiG-21 vegvliegtuie met die SA Lugmag gebots en een is deur ' $n$ Mirae neergeskiet. Operasie Daisy is op 20 November 1981 beëindig.

\section{Operasie Super (1982)}

Vroeg in 1982 het dit duidelik geword dat SWAPO besig was met voorbereidsels om ' $n$ nuwe front in Kaokoland te open. Verkenningselemente van 32 Bataljon is ingestuur om SWAPO-terrorise wat die gebied sou insypel, op te spoor. Sowat 250 terroriste is by ' $n$ versamelgebied naby die dorpie lona in die suidweste van Angola aangetref van waar hulle SWA wou binnesypel. Hierna is 75 soldate na die gebied ingevlieg om 'n blitsaanval te loods. Dertig soldate is as stoppergroepe ontplooi terwyl die hoofmag van 45 man die aanval van stapel laat loop gestuur het. Ofskoon die terroriste 'n groot getalsoorwig geniet het, is hulle algeheel verras en oorrompel; altesame 201 terroriste is dood terwyl slegs 2 man van 32 Bataljon lig gewond is. ' $n$ Groot hoeveelheid ammunisie en wapentuig is gebuit.

\section{Operasie Meebos (1982)}

Operasie Meebos is in Julie en Augustus 1982 geloods en het bestaan uit ' $n$ aantal lugaanvalle op SWAPO se bevel- en beheerstelsel. Altesaam 345 terroriste is dood en SWAPO se sg "oosfront"-hoofkwartier by Mupa is vernietig voordat dit verskuif kon word. Die veiligheidsmagte het 29 soldate verloor van wie 15 in een voorval omgekom het toe 'n Puma-helikopter neergeskiet en al die insittendes dood is.

\section{Operasie Phoenix (1983)}

In die eerste helfte van Februarie 1983 het SWAPO ' $n$ nuwe offensief geloods in ' $n$ poging om sy verlore aansien te herwin. 'n Spesiale eenheid van sowat 1700 terroriste wat in verskillende kompanies ingedeel is, het vanaf $13 \mathrm{Fe}$ bruarie begin om Owambo binne te sypel en die eerste groot kontak het op 15 Februarie plaasgevind toe 15 terroriste dood is. Die veiligheidsmagte se teenoptredes (Operasie Phoenix) was uiters geslaagd en met die beëindiging van die operasie op 13 April 1983 het 309 SWAPO-terroriste reeds gesneuwel. Die veiligheidsmagte het 27 man verloor.

\section{Operasie Askari (1983)}

Teen die einde van 1983 het dit duidelik geword dat SWAPO besig was om 'n grootskaalse insypeling vir vroeg 1984 te beplan. Operasie Askari, wat hoofsaaklik gemik was op die ontwrigting van PLAN se logistieke infra-struktuur en bevel- en beheerstelsel dmv verskeie lug- en grondaanvalle, is op 6 Desember 1983 van stapel gestuur. Ofskoon die aanvalle op PLAN toegespits was, het FAPLA-magte in die gevegte betrokke geraak en verskeie botsings met die Angolsese het gevolg.

Vier gemeganiseerde veggroepe van 500 man elk het spesifieke teikens aangeval terwyl kleiner infanteriegroepe gebiedsoperasies in die grensarea uitgevoer het.

Die grootste botsing tussen die SA magte en FAPLA het op 3 Januarie 1984 voorgekom toe FAPLA se 11de Brigade en twee Kubaanse bataljons SWAPO te hulp gesnel het toe sy hoofkwartier en basis vyf kilometer van Cuvelai aangeval is. Hierdie mag is egter verdryf nadat dit 324 man verloor het; die meeste van die veilig- 


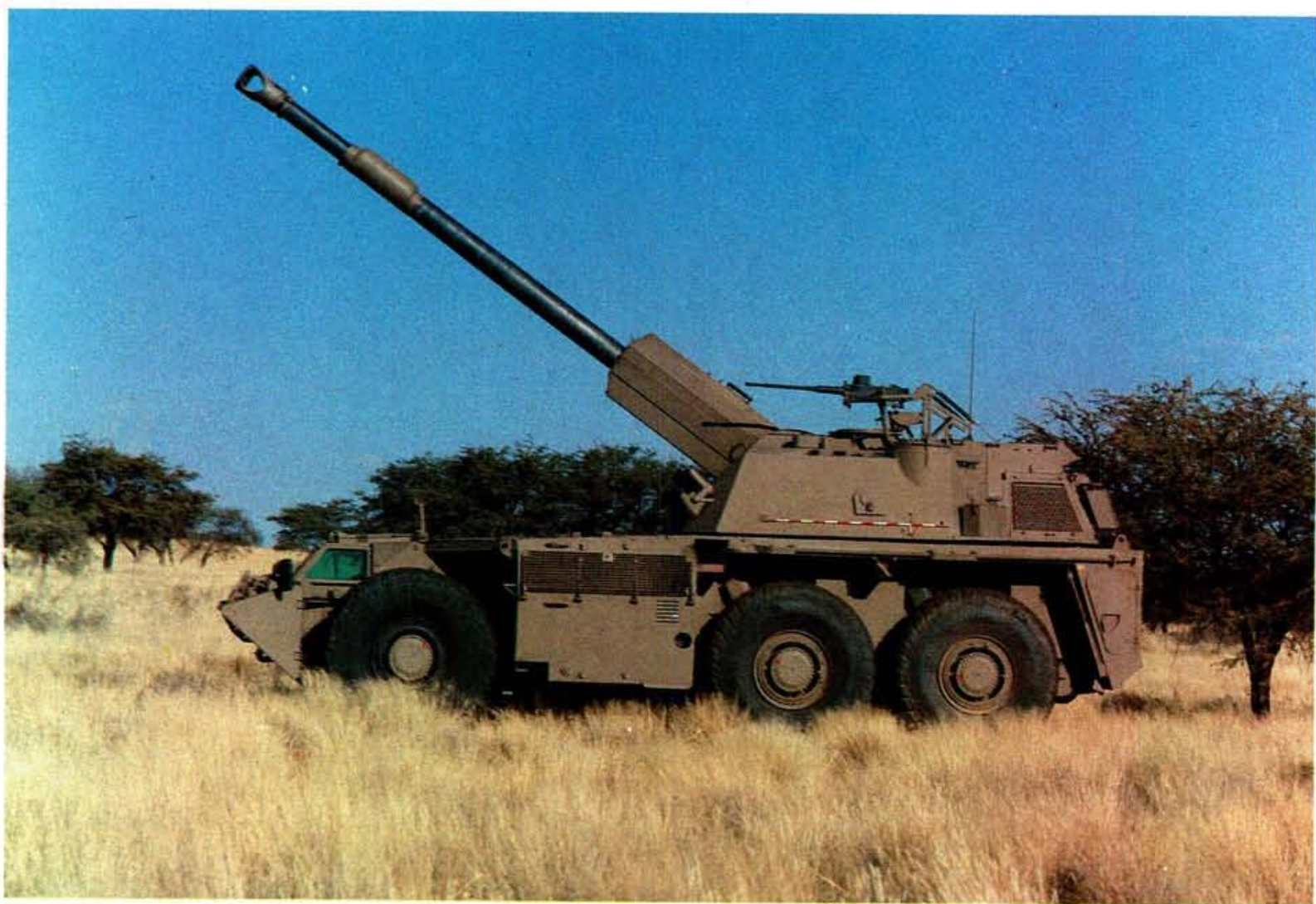

Die G6-sefaangedrewe medium kanon is deur KRYGKOR ontwikkel en is gebore uit die ervaring van die Suid-Atrikaanse Artillerie in Operasie Savannah en latere krygsoperasies

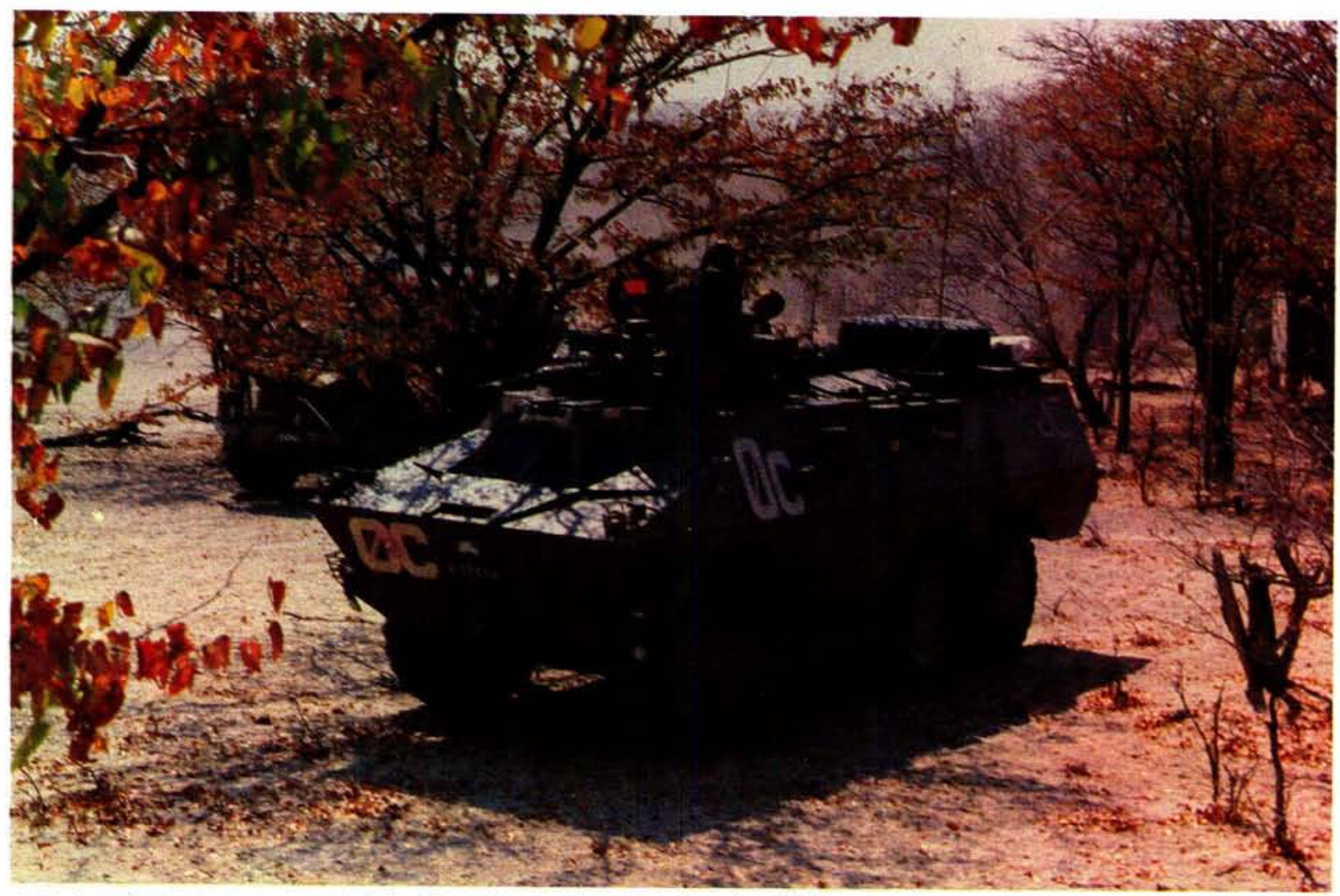

'n Ratel-infanteriegevegsvoertuig in die suide van Angola tydens 'n militêre operasie teen SWAPO-terroriste. Die Ratelinfanteriegevegsvoertuig is die troepedraer van die gemeganiseerde infanterie. Die Ratel is met groot welslae in voorsprongoperasies soos onder meer Operasie Reindeer teen SWAPO-basisse aangewend 


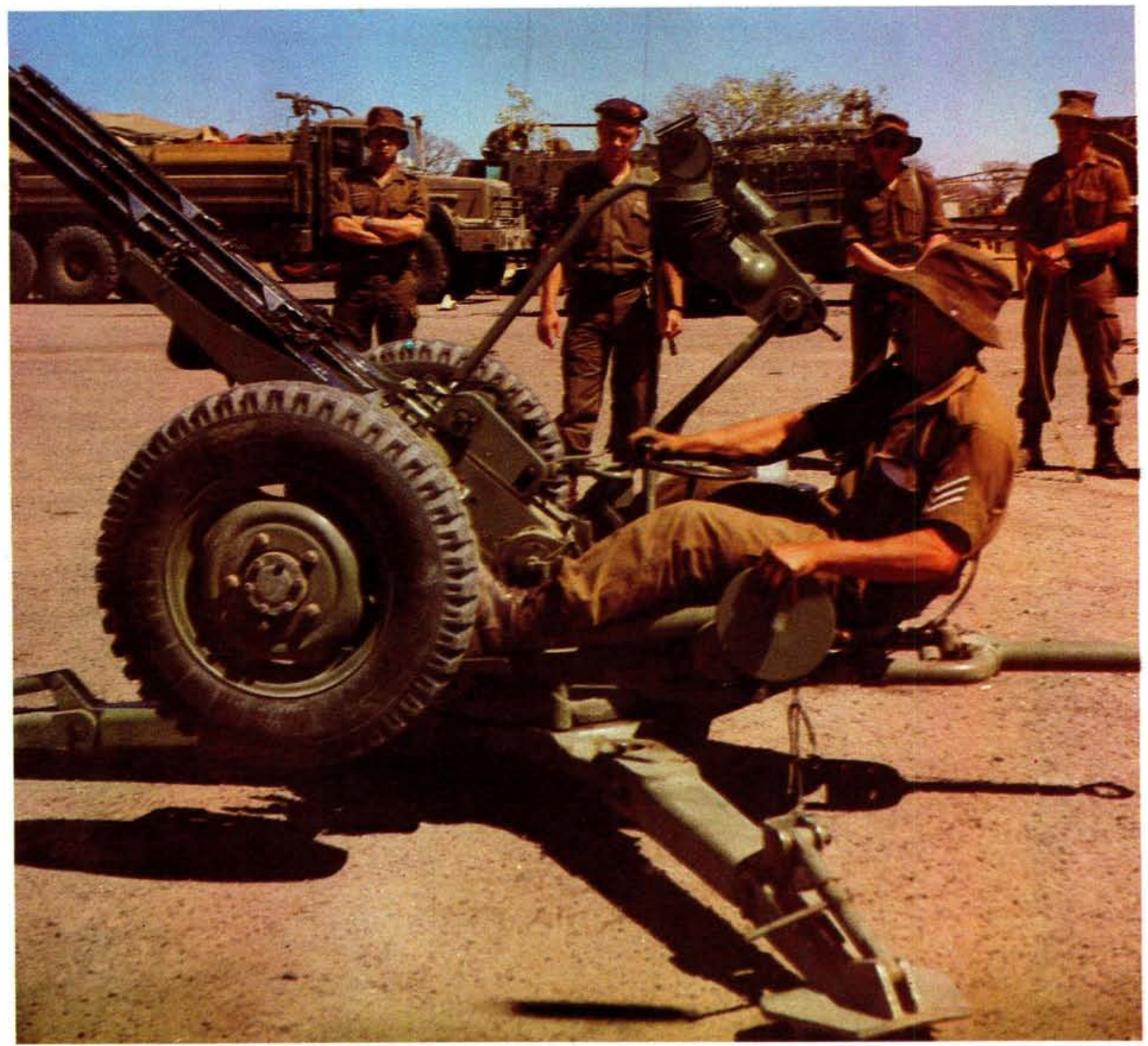

Lede van die Suid-Afrikaanse magte by 'n lugafweerkanon wat in 'n operasie van SWAPO gebuit is

heidsmagte se 21 ongevalle in Operasie Askari is tydens hierdie botsing gely.

Operasie Askari het op 13 Januarie 1984 ten einde geloop. Die SA magte se onttrekking is deur swaar reëns en oorstromings vertraag. Die belangrikste gevolg van Operasie Askari was dat dit Angola gedwing het om in Lusaka samesprekings met SA te voer oor 'n staking van vyandelikhede in Suid-Angola.

Samesprekings is in Lusaka gehou en in Februarie 1984 is die Lusaka-ooreenkoms gesluit waarvolgens ' $n$ Gesamentlike Monitorkommissie die onttrekking van Suid-Afrikaanse troepe aan Angola sou monitor. Angola het onderneem om toe te sien dat geen SWAPO-terroriste of Kubaanse magte die gebiede wat deur die SA magte ontruim is, betree nie. Die onttrekking van
SA magte het egter langsaam plaasgevind en kon eers in April 1985 afgehandel word.

\section{Operasie Boswilger (1985)}

$\mathrm{Na}$ die veiligheidsmagte se onttrekking aan Angola in April 1985, het SWAPO-terroriste die situasie uitgebuit en opnuut begin om vanaf basisse in Angola oor die grens te opereer. Die veiligheidsmagte moes noodgedwonge optree.

Gedurende Operasie Boswilger, wat op 29 Junie 1985 begin en slegs 48 uur geduur het, is die spore van SWAPO-terroriste tot by hul basisse in drie verskillende gebiede in Angola gevolg. Op die eerste dag is 43 terroriste dood en een gevang in 23 kontakte. Op die tweede dag is 14 terroriste dood en vier gevang in 13 kontakte. Hierna het die veiligheidsmagte oor die grens teruggetrek. 


\section{Operasie Moduler en Operasie Hooper (1987 - 1988)}

Die Suid-Afrikaanse magte het die UNITA-weerstandsbeweging gedurende Operasie Moduler (1 Julie - 15 Desember 1987) militêr ondersteun ten einde die aanmars van die FAPLA-magte op Mavinga en Jamba suid van die Lombarivier te stuit.

Die FAPLA-magte in sentraal-oos-Angola het aanvanklik goed gevorder, maar is deur UNITA verslaan en moes terugtrek. FAPLA se suidwaartse offensief vanaf Cuito Cuanavale het op 14 Augustus 1987 met ses brigades begin. Inligting het daarop gedui dat FAPLA ' $n$ groot aantal gepantserde voertuie rondom Cuito Cuanavale ontplooi het. 'n Suid-Afrikaanse span is tot UNITA toegevoeg met die doel om te help in die voorbereiding van die weerstandsbeweging se tenkafweer-strategie. Die Suid-Afrikaanse magte sou ook, indien nodig, lug- en artilleriesteun verskaf.

Die FAPLA-magte het goeie vordering gemaak ondanks die feit dat UNITA sy logistieke ondersteuning in sy agterhoede belemmer het. Die ontplooiing van die Suid-Afrikaanse gemeganiseerde mag het verhoed dat FAPLA die Lombarivier kon oorsteek en in hul poging om 'n brughoof te vestig, het sy brigades aansienlike verliese gely. In die gevegte op 13 en 14 September het UNITA 40 en die Suid-Afrikaanse

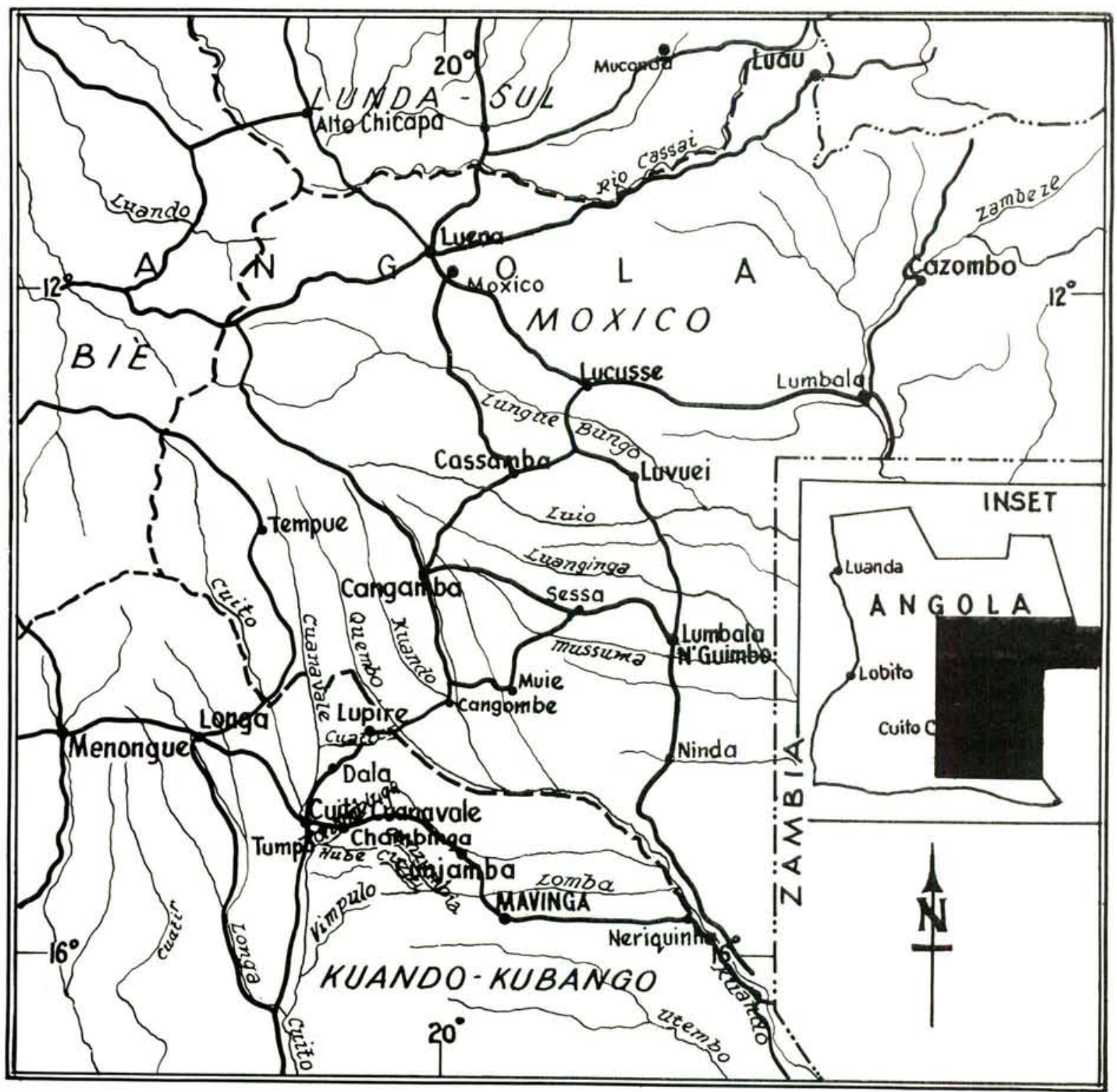

Kaart van die gebied om Cuito Cuanavale waar die FAPLA-magte gedurende Operasie Moduler en Hooper vasgepen is. Cuito Cuanavale was nooit 'n teiken van die Suid-Afrikaanse magte nie 
ondersteuningsmag ses soldate verloor teenoor die 382 van die FAPLA-magte.

Die ergste botsing het op 3 Oktober plaasgevind en FAPLA is ' $n$ verpletterende nederlaag toegedien. Die oorblyfsels van FAPLA se magte het hierna by die oorblywende brigades noord van die rivier aangesluit. Hierna het FAPLA tot om Cuito Cuanavale teruggetrek.

Op hierdie tydstip was FAPLA wel nog in staat om 'n nuwe offensief te loods. UNITA en die Suid-Afrikaanse ondersteuningsmag kon dus nie terugtrek nie en opdrag is gegee dat alle FAPLA-brigades oos van die Cuitorivier vernietig of teruggedryf moes word. Hierna moes die Cuitorivier in 'n hinderlaag vir FAPLA omgeskep word.

Voorraad-aanvulling en lugsteun van die FAPLAmagte is verder beperk en hul hoofkwartier is gedwing om terug te trek na Nancova. Tussen 9 en 16 November was die Suid-Afrikaanse mag by ' $n$ verdere groot botsing in die omgewing van die Chambinga- en Humberivier betrokke. In hierdie gevegte is 16 Suid-Afrikaanse soldate dood terwyl FAPLAS 525 man en 'n groot hoeveelheid wapentuig verloor het. Operasie Moduler is teen die middel van Desember 1987 beëindig en deur Operasie Hooper opgevolg.

Bykomende FAPLA-magte is na die afloop van Operasie Moduler na Cuito Cuanavale verskuif en volgens UNITA het FAPLA nou oor 25000 man beskik. Die Suid-Afrikaanse mag het G-5 kanonne effektief aangewend om hierdie sametrekking van FAPLA-magte wes- en noordwaarts te verdryf. Aangesien FAPLA steeds 'n bedreiging gebly het, het die Suid-Afrikaners UNITA bly ondersteun in sy poging om die FAPLAmagte uit die gebied tussen die Cautir- en Chambingarivier te verwyder.

FAPLA se 21ste Brigade, wat langs die Cuatirrivier ontplooi was, is op 13 Januarie 1988 uit die gebied verdryf. Daar was geen verliese aan Suid-Afrikaanse kant nie, maar FAPLA moes 'n verdere 250 man en 'n groot hoeveelheid wapentuig inboet. Op 14 Februarie is ' $n$ aanval op FAPLA se 59ste Brigade geloods en na 'n onsuksesvolle FAPLA-teenaanval, waarin die vyand onder meer 230 man en 9 tenks verloor het, moes hierdie brigade terugtrek.

UNITA, ondersteun deur Die Suid-Afrikaanse ondersteuningsmag, het op 25 Februarie die stellings van FAPLA se 21-, 25- en 59ste Brigades by die Tumporivier en Dala aangeval. Hierdie aanvalle waartydens FAPLA aansienlike verliese gely het, het meegebring dat die FAPLA-magte effektief in 'n voorafbepaalde gebied by Cuito Cuanavale vasgepen is en die gebied kon in ' $n$ hinderlaag omgeskep word. Hierna het die SuidAfrikaanse magte voortgegaan met 'n taktiese ontkoppeling wat reeds in Desember 1987 begin het.

Die Suid-Afrikaanse magte se ingryping in Angola tydens hierdie operasies het 'n grootskeepse FAPLA-oorwinning oor UNITA afgeweer en voorkom dat SWAPO toegang tot die noordoostelike deel van SWA verkry. Die Suid-Afrikaanse taakmag se verliese was gering: 31 Suid-Afrikaanse soldate en 12 lede van die SWA Gebiedsmag. Hierteenoor het FAPLA meer as 7000 man en 'n groot hoeveelheid wapentuig verloor.

\section{Operasies Packer en Displace (1988)}

Tydens Operasie Packer, wat Operasie Hooper in Maart 1988 opgevolg het, het 82 Gemeganiseerde Brigade (wat grotendeels uit Burgermaglede bestaan), voortgegaan om om die oostelike oewer van die Cuitorivier te beskerm. Gedurende hierdie operasie het die FAPLA-magte weer eens swaar verliese gely en die situasie aan die oostelike oewer het sodanig gestabiliseer dat 'n aanvang met Operasie Displace gemaak kon word. Gedurende hierdie fase het die Suid-Afrikaanse magte aan Angola onttrek.

\section{Konflik by Calueque (1988)}

'n Gesamentlike FAPLA-Kubaanse mag het op 27 Junie eers ' $n$ grondaanval en daarna 'n verraderlike lugaanval deur MiG-vegvliegtuie op die Calueque-waterskema geloods. Die grondaanval is gestuit deur 'n beskermingsmag van die SAW en die SWA GM. Twaalf SA soldate en meer as 300 Kubane en Angolese het in die twee skermutselinge omgekom.

Hierdie konflik het die onderhandelinge oor die beëindiging van vyandelikhede en die implementering van die VN se Resolusie 435 in SWA, bykans verongeluk.

\section{SLOT}

Op 2 Augustus 1988 het Suid-Afrika tydens samesprekings in Genève 'n aantal vredesvoorstelle voorgelê. Hierdie voorstelle het eerstens 


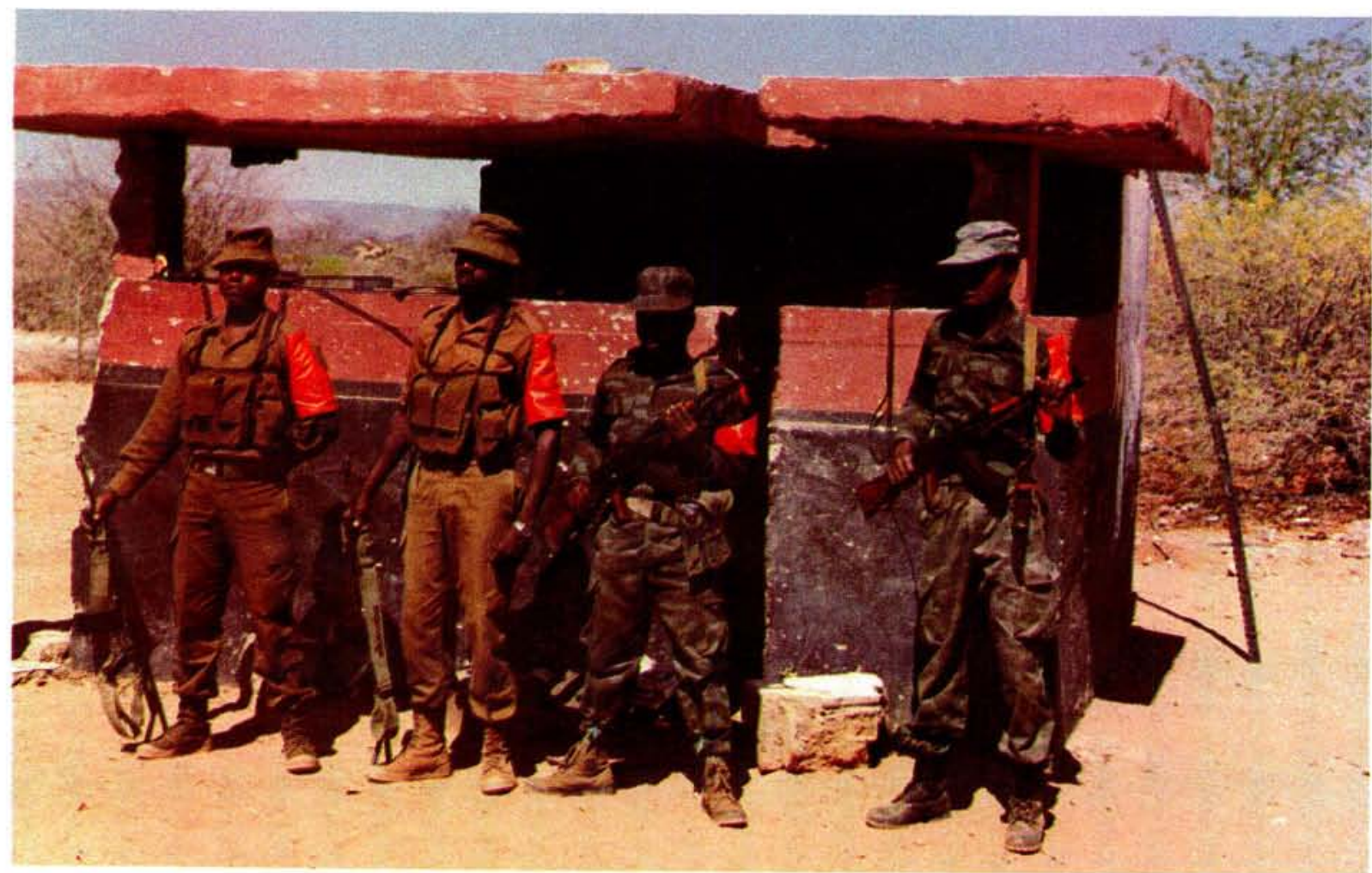

Militêre personeel van die Gesamentlike Militêre Kommissie wat op 30 Augustus 1988 tot stand gekom om die onttrekking van Suid-Afrikaanse magte aan Angola en die staking van vyandelikhede te monitor. Die foto is by 'n grenspos naby Ruacana geneem

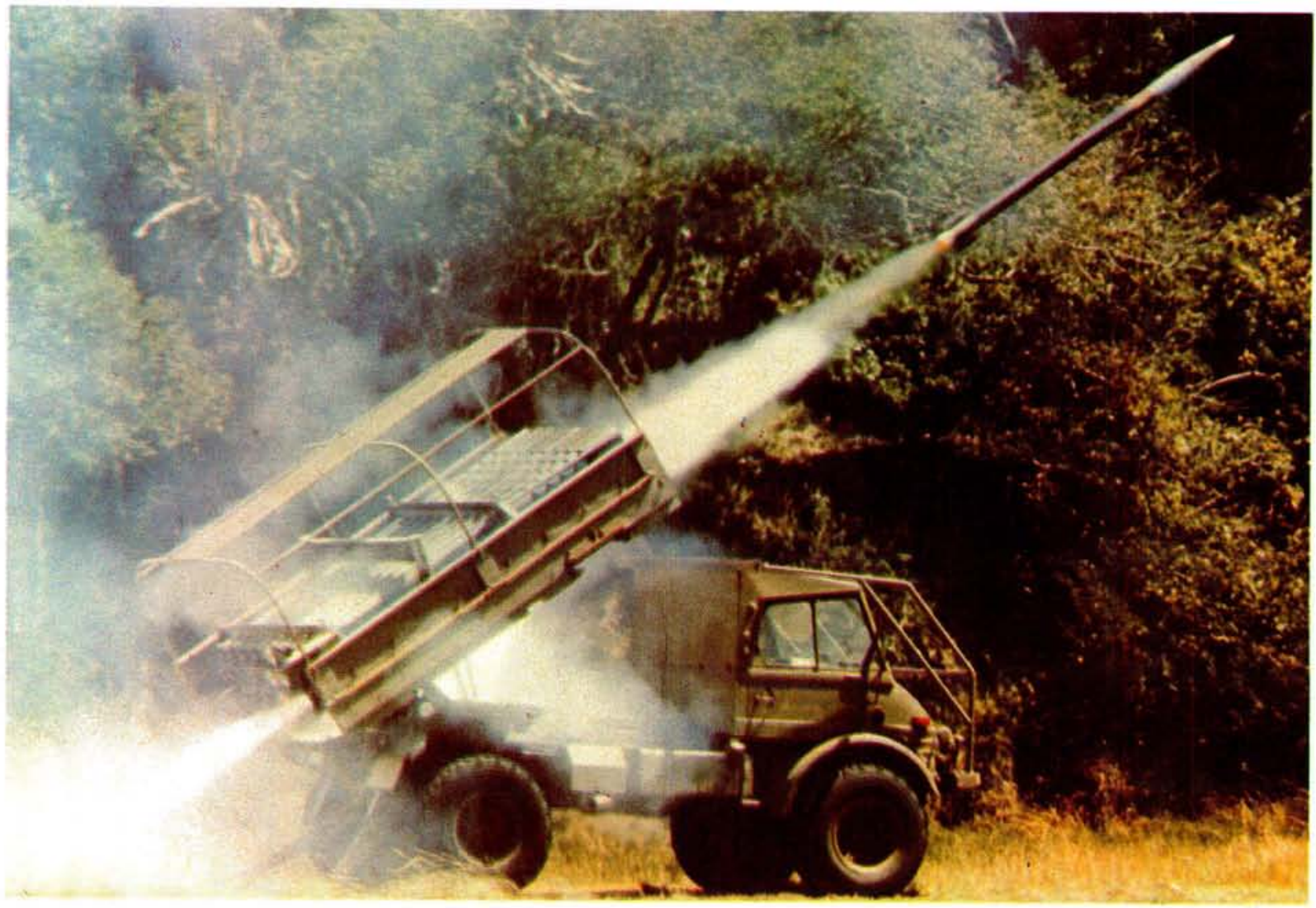

Die Valkiri 127-mm meervoudige vuurpyllanseerder is plaaslik vir die Suid-Afrikaanse Leër ontwikkel as teenvoeter vir die Russiese BM-21 stelsel wat die Suid-Afrikaanse magte probleme gedurende Operasie Savannah besorg het. Die Valkiri is sedert 1981 met groot welslae in operasies aangewend 


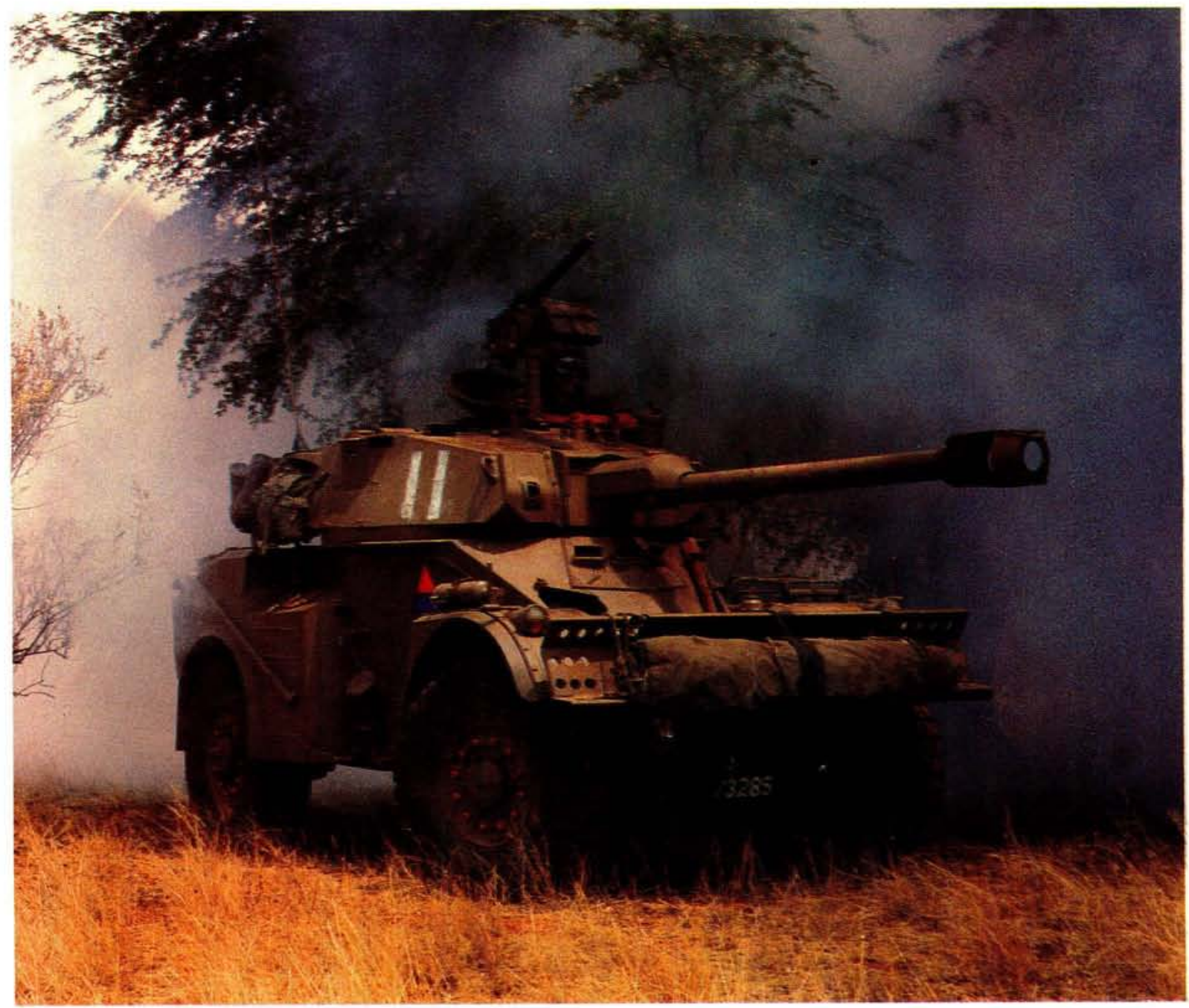

Die Eland 90-pantserkar, die Suid-Afrikaanse magte se primêre pantserwapen in operasies in Angola en Suidwes-Afrika

voorsiening gemaak vir die staking van alle vyandelikhede in die gebied vanaf 10 Augustus 1988. Tweedens moes onverwyld 'n aanvang gemaak word met die onttrekking van vreemde magte aan Angola. Suid-Afrika het die onderneming gegee dat die onttrekking van sy magte op 1 September 1988 afgehandel sou wees.

Op 22 Augustus 1988 het militêre verteenwoordigers van die RSA, Angola en Kuba 'n verdrag by Ruacana onderteken wat vir die staking van vyandelikhede voorsiening gemaak het.

Op 1 September 1988 was die onttrekking van die Suid-Afrkaanse magte aan Angola afgehandel. Die einde van die militêre stryd in SWA was reeds in sig.

Verdere samesprekings in die tweede helfte van 1988 het uiteindelik uitgeloop op die ondertekening van twee belangrike ooreenkomste op 22
Desember 1988 in New York. Die drieparty-ooreenkoms tussen die RSA, Kuba en die MPLAbewind het voorsiening gemaak vir die implementering van Resolusie 435 van die VN se Veiligheidsraad en die onttrekking van die SuidAfrikaanse magte aan SWA in die tydperk vanaf 1 April 1989 totdat SWA onafhanklik word. Tweedens het ' $n$ bilaterale ooreenkoms tussen Kuba en Angola voorsiening gemaak vir die onttrekking van die Kubaanse magte aan Angola oor 'n tydperk van 27 maande. Met hierdie ooreenkomste is die weg gebaan vir ' $n$ vreedsame bedeling in suidwestelike Afrika.

SWAPO het die sogenaamde "bosoorlog", wat in 1966 by Ungulumbashe in Wes-Owambo begin het, verloor. Die organisasie kon nie daarin slaag om een groot gewapende botsing met die veiligheidsmagte te wen nie. Sy ideaal om deur middel van rewolusionêre geweld in SWA aan bewind te kom, het dus misluk. 
Die prys wat SWAPO vir sy mislukte revolusionêre aanslag moes betaal, was hoog: vanaf daardie eerste skermutseling op 26 Augustus 1966 tot aan die einde van 1988, is 11335 terroriste in gevegte met die veiligheidsmagte dood.

Sedert 1978 (toe die eerste voorsprongoperasie geloods is), het SWAPO se mannekragsituasie algaande versleg. In 1978 het dit nog oor ongeveer 16000 opgeleide terroriste beskik, dog in die volgende nege jaar het dit tot 8700 gedaal (Desember 1987). In 1988 het SWAPO se mannekragsituasie verder verswak.

Die welslae van die veiligheidsmagte se operasies teen SWAPO-basisse in die afgelope 10 jaar het ook tot ' $n$ beduidende uitwerking op terroristebedrywighede in SWA gehad. Die aantal terroristevoorvalle jaarliks het weliswaar vanaf 462 in 1978 tot 1175 in 1980 toegeneem, maar hierna het dit afgeneem tot 483 in 1987.

Vir Suid-Afrika is die onttrekking van sy magte aan SWA geen vernedering of nederlaag nie. Die Suid-Afrikaanse magte het as oorwinnaar uit die stryd getree, hul sending suksesvol afgehan- del: hulle het SWA en sy inwoners beskerm en SWAPO verhoed om deur middel van rewolusionêre geweld die bewind in SWA oor te neem. Die RSA se militêre vermoë het grootliks tot groter stabiliteit en vrede in suidwestelike Afrika bygedra.

- Kol C.J. Nöthling MA is verbonde aan die publikasieseksie D.O.B.

\section{Bronnelys}

Heitman, Helmoed-Römer, "Angola - South African operations", Defence 2000, Vol 3 no 10 (June 1988), pp 28-37.

Heitman, Helmoed - Römer: South African War Machine, CNA, Johannesburg 1985.

James, W. Martin III, "Cuban involvement $n$ the Angolan Civil War: Implications for lasting peace in Southern Africa", ISSUP Bulletin 4/88, Instituut vir Strategiese Studies, Universiteit van Pretoria 1988.

Kleynhans, A.S.J.: Die stryd teen terreur in SWANamibië, SWA Gebiedsmag, Windhoek 1988.

Menaul, Stewart: The Border Wars: South Africa's Response, Conflict Studies No 152, Institute for the Study of Conflict, Londen 1983.

Militêre Informasieburo (Suid Afrikaanse Weermag): Militêre Geneeskunde in Suid-Afrika (1913-1983), Publikasie no 7, Pretoria 1983.

Militêre Informasieburo (Suid-Afrikaanse Weermag): Ultima Ratio Regum, Publikasie no 8. Pretoria 1987.

Militaria 17/1 (1987): "Aktiewe diens in Suider-Atrika", p. 56.

Paratus (Junie 1983): "SWAPO killers blocked", pp 46.

Paratus (Augustus 1985): "SWAPO ignored warnings and paid heavy price", pp 10-13.

Paratus (Maart 1988): "Cuito Cuanavale: Veil lifted at last", p 14.

Pergamus (Oktober 1987): "The War in SWA/Nambibië, pp 7-8. Steenkamp, Willem: Borderstrike!, Butterworths Publishers, Durban/Pretoria 1983. Venter, ALJ, et al: Challenge - Southern Africa within the African Revolutionary Context, Ashanti, Gibraltar 1989. 